W stużbie tradycji i odnowy liturgicznej. 50 lat Instytutu Liturgicznego w Krakowie (1968-2018), red. P. Nowakowski, J. Mieczkowski, Kraków 2019, s. 285-300.

ISBN 978-83-7438-849-8 (wersja drukowana), ISBN 978-83-7438-850-4 (wersja online)

DOI:http://dx.doi.org/10.15633/9788374388504.22

\title{
Liturgical sources and liturgical theology at the Institute of Liturgical Sciences in Fribourg (Switzerland)
}

The Second Vatican Council described the liturgy as the source and summit of the life of the Church as a whole, but also of the individual believers (SC 10). ${ }^{1}$ During the twentieth century, liturgical scholarship has profiled itself as a theological subject that deals scientifically with worship. No other discipline has received comparable support from the last council (see, in particular, art. 16 of the liturgical constitution). The Catholic theological faculties in Switzerland have responded differently to the requirements of Vatican II. The study of the liturgy at the University of Fribourg has its special place and its special history. ${ }^{2}$

1 "Nevertheless the liturgy is the summit toward which the activity of the Church is directed; at the same time it is the font from which all her power flows. For the aim and object of apostolic works is that all who are made sons of God by faith and baptism should come together to praise God in the midst of His Church, to take part in the sacrifice, and to eat the Lord's supper."

2 On the history of liturgical science at the University of Freiburg, regarding persons, studies and projects see the extensively informing volume: Der Zeit voraus - Devancer son 


\section{History and goals of the Institute of Liturgical Science}

\subsection{The beginning of the Liturgical Sciences at the University of Fribourg 1900-1955}

The Faculty of Theology of the University of Fribourg 3 broke new ground in the international context by creating a Chair of Liturgical Science between 1900 and 1912; its holder was Prince Max von Sachsen (1870-1951), who was particularly devoted to the liturgy of the Eastern Churches. After losing his chair because of a seemingly harmless publication on an ecumenical topic, aspects of the subject in pastoral theology and ancient church history (archaeology) were taught, as was often the case at that time. Max von Sachsen was never replaced, so the chair was no longer active after his departure.

In connection with the beginnings of the Liturgical Renewal, the Faculty of Theology created a course in liturgical sciences which was taught by the Luxembourg Benedictine Jean Hild OSB (1911-1974) of the Abbey of Clairvaux from 1953 to 1956.4

\subsection{The creation of the Chair before the Second Vatican Council}

In the early 1950s, in the light of new theological currents and ecclesiastical processes, the Swiss Bishops' Conference endowed the establishment

époque. Liturgiewissenschaft an der Universität Freiburg Schweiz: Geschichte, Konzepte, Projekte. 1956-2006. La science liturgique à l'Université de Fribourg Suisse: Histoire, concepts, projets, sous la rédaction de M. Klöckener, B. Bürki, Fribourg 2011.

3 On the history of the Faculty of theology of Fribourg during the first half century of its existence see D. Barthélemy, M.-H. Vicaire, Dirk van Damme, La Faculté de Théologie, in: Histoire de l'Université de Fribourg 1889-1989, Vol. 2, Les Facultés, Fribourg 1991, p. 475-559. See also between 1887 and 1913, the review Divus Thomas that became Jahrbuch für Philosophie und spekulative Theologie (1914-1953) then Freiburger Zeitschrift für Philosophie und Theologie, from 1954 until today. See also D. Barthélemy, Idéologie et Fondation, Fribourg 1991 (Études et documents sur l'histoire de l'Université de Fribourg Suisse / Studien und Dokumente zur Geschichte der Universität Freiburg Schweiz. Études, 1), p. 50-81.

4 See M. Klöckener, Vorgeschichte und Errichtung des Lehrstuhls für Liturgiewissenschaft an der Universität Freiburg (Schweiz) im Jahre 1956, in: Der Zeit voraus - Devancer son époque, p. 20-56. 
of its own professorship for liturgical science and a liturgical institute at the University of Fribourg.

A new permanent Chair of Liturgical Science was created in 1956, before the Second Vatican Council. Anton Hänggi5 (1917-1994) was its first holder until his election as bishop of Basel in 1967. A historian by training, Mgr. Hänggi was mainly involved in historical research. Nevertheless, he participated in many commissions as part of the preparation and implementation of the liturgical Reform desired by the Second Vatican Council. It can certainly be said that he exerted a notable influence on the renewal of the liturgical life of the Catholic Church. He was co-founder in 1957 of the Spicilegium Friburgense collection and in 1963 Spicilegii Friburgensis Subsidia for the edition of "texts to serve the history of the Christian life", especially for the edition of liturgical sources.

In 1963, the Liturgical Institute of the Swiss Bishops' Conference was set up on the initiative of Hänggi and initially attached to the chair. In 1968, his German-speaking section was moved to Zurich after the episcopal appointment of Hänggi. After a brief stay in Lucerne from 2001 to 2003, the Liturgical Institute for German-speaking Switzerland Liturgisches Institut der deutschsprachigen Schweiz, returned in 2004 to its place of origin, Fribourg. The French section, now Centre Romand de Pastorale Liturgique, remained in Fribourg until 1996, when it moved to La Pelouse, in Bex, Canton of Vaud. The Italian section has been in Lugano since the conciliar period.

\subsection{The development following the Council 1969-1992}

\subsubsection{Jakob Baumgartner SMB and the implementation of the Council}

Jakob Baumgartner SMB ${ }^{6}$ (1926-1996) was elected as a successor to Hänggi and was a professor from 1969 until his retirement in 1991. He devoted

5 A brief bibliography of Anton Hänggi, in: Der Zeit voraus - Devancer son époque, p. 211-215. For further information concerning his life and work see: M. Klöckener, Bio-Bibliographisches Repertorium der Liturgiewissenschaft, Folge 3 für die Jahre 1998-2012. Mit Nachträgen aus früheren Jahren, "Archiv für Liturgiewissenschaft" 56 (2014), p. 136-222, especially p. 165, no 3119.

6 For a short bibliography of Jakob Baumgartner see Der Zeit voraus - Devancer son époque, p. 216-221. For a more detailed presentation of his work and the complete bibliography, see M. Klöckener, Liturgie und Mission. Zum wissenschaftlichen Werk von Jakob Baumgartner SMB 
himself more particularly to the realization of the liturgical reform under way from the point of view of liturgical pastoral care. He also understood his teaching and the liturgical sciences as a bridge between French- and German-speaking languages and cultures. Moreover, he engaged outside the University with conviction through lectures and publications for the implementation of conciliar decisions.

\subsection{The Institute of Liturgical Science 1992 - until today}

\subsubsection{Martin Klöckener and the strengthening of international collaborations}

For a few years the Reformed theologian Bruno Bürki (was born 1931), after gaining habilitation from the University of Fribourg Theological Faculty in 1981, took over the teaching and research responsibilities with the result of numerous publications and other outputs. ${ }^{7}$

In October 1994, the German theologian Professor Martin Klöckener (was born 1955) was appointed to the bilingual chair. As an ordinary professor, he is responsible for representing the discipline in all its variety through teaching, research and continuing education.

Thanks to the important developments in research and to the various international collaborations established over the years, the Faculty of The-

(1926-1996) mit einer Bibliographie seiner Schriften 1986-1997, "Archiv für Liturgiewissenschaft" 38/39 (1996/1997), p. 273-304. For further information concerning him, see M. Klöckener, Bio-Bibliographisches Repertorium der Liturgiewissenschaft, Folge 3, especially p. 143, no 3022.

7 See a brief bibliography of Bruno Bürki, in: Der Zeit voraus - Devancer son époque, p. 235239, including the monography Bénédiction nuptiale à l'horizon œecuménique, Fribourg 2011. His complete bibliography until 2001 has been published by A. Join-Lambert, Bibliographie Bruno Bürki (Stand: Juli 2001), in the Festschrift dedicated to him: Liturgia et Unitas. Liturgiewissenschaftliche und ökumenische Studien zur Eucharistie und zum gottesdienstlichen Leben in der Schweiz. Études liturgiques et œcuméniques sur l'Eucharistie et la vie liturgique en Suisse. In honorem Bruno Bürki, ed. by M. Klöckener, A. Join-Lambert, Freiburg-Geneva 2001, p. 42-54. For the following years until 2011 see M. Klöckener, Ökumenische Liturgiewissenschaft. Bibliographie Bruno Bürki für die Jahre 2002-2011, "Archiv für Liturgiewissenschaft" 53 (2011), p. 120-130. For further information about him, see M. Klöckener, Bio-Bibliographisches Repertorium der Liturgiewissenschaft, Folge 3, especially p. 149, no 3051. 
ology has brought together the activities of the chair under the umbrella of a new Institute which was set up in 1999. The purpose of the creation of the Institute was mainly to strengthen research at a time when there were no separate chairs of liturgical science at the other Swiss theological faculties. Since then, this task has been consistently carried out. The institute is today part of a broad international network connected with the professional world primarily in Germany, Austria, France (Institut Supérieur de Liturgie at the Institut Catholique de Paris) and Italy. Expressly mentioned are also the good contacts with the colleague in Chur/Lucerne. Through the founding of this Institute, the University of Fribourg wanted to highlight the importance of teaching and research in liturgical sciences and strengthen the theological field for the future.

At a Swiss level, the conventionally regulated cooperation with the liturgical institute for German-speaking Switzerland - Liturgisches Institut der deutschsprachigen Schweiz, ${ }^{8}$ which has been back in Fribourg since 2004, should be emphasized. Both institutes collaborate at conferences for further education (for example at the annual event "Liturgie im Gespräch Liturgy in Discussion") or through scientific and pastoral counselling. In addition, there are various services of the Institute for liturgical studies for church authorities and commissions. Scientifically qualified staff of the Liturgisches Institut also take duties to teach at the university, so that both sides benefit from this fruitful exchange.

\section{University and academic features}

The University's bilingual character (German/French) offers opportunities for meetings and exchanges related to different points of view, theological traditions, life forms, mentalities and cultures in the field of liturgy. Due to the many international links in teaching and research and important publications in recent decades, the liturgical sciences at the University of Fribourg are known in Switzerland and beyond. They are among the strengths of the Faculty.

8 https://www.liturgie.ch/ (22.09.2018). 
Teaching and research in liturgical sciences are at the heart of the Institute's activity. In addition to coordinating the teaching of this theological discipline at the University of Fribourg, the Institute conducts research projects from an interdisciplinary perspective, with a special focus on the liturgy, its history and the new approaches to its study and influence on the religious ethos in Switzerland. The institute is equally engaged in continuing education in liturgical and pastoral work and in promoting collaboration with other universities and academic institutions at national and international levels.

\section{Main focuses in teaching and research at the Institute of Liturgical Science}

\subsection{Teaching}

The courses are to be guaranteed in both languages German and French. In addition to the chair holder, guest professors and lecturers from Switzerland, Germany, France and other countries regularly contribute, ensuring a rich offer for both normal study and liturgical specializations.

The training objectives indicate mainly that the students will acquire skills in different areas as: the theology and history of the Christian liturgy; the structures and elements of liturgical celebrations; the celebration of the Eucharist and other sacraments; the liturgies of the Word; the basic structures of the liturgical year; and the liturgy of the hours.

Through the courses the students develop competences in order to be able to apply the skills learned in various contexts as ecclesial ministries, with a view to preparing and evaluating liturgical practices or to understand pastoral liturgy better. They also develop scientific research for the interpretation of past and current liturgical sources and for a theological analysis of liturgical actions in an ecumenical perspective. Intra- and extra-ecclesial areas are also examined for an in-depth understanding of the liturgy, of its ritual structures, of its anthropological conditions and of the implications of the contemporary societal context. 


\subsection{Training structures}

The formation in liturgical sciences is divided into two stages:

- basic training in the $1^{\text {st }}$ and $2^{\text {nd }}$ years of the Bachelor of Theology;

- thematic deepening in Master of Theology.

For the Bachelor's degree, the main courses "Introduction to Liturgical Sciences I and II" provide the historical, theological and epistemological foundations of the liturgical sciences and also study the liturgical year. The accompanying seminars for introductory courses allow for the deepening of the course content as well as a reflection on the personal liturgical experience. Each semester a seminar is offered on a specific theme. Other types of education, such as practice-oriented study days, enrich the basic curriculum. Excursions make it possible to discover characteristic places for liturgical studies and to enrich the experience of the liturgy.

Main courses on more specific topics are offered for Master's students. Each semester a seminar is proposed on a specific theme. As with the Bachelor's, the Master's courses include practice-oriented study days and enriching excursions.

Finally, an additional programme is offered to students who specialize in liturgical sciences (MA with specialization) as well as to licence and doctoral students. These doctoral colloquia which provide each researcher with the opportunity to engage with peers and present the actual state and development of their theses have been so far the laboratory of 2 completed habilitations and 13 completed PhDs in Theology - Liturgical sciences, in research areas such as rites in different contexts, liturgies of diverse families, studies on sacraments, Eucharistic prayers, Eucharistic theology, Eucharistic spirituality, history of the liturgy (Ancient Church and Middle Ages), etc. ${ }^{9}$ Another 14 doctoral students are in the process of writing their doctoral theses on topics such as Cistercian rites and liturgical reforms, liturgical-anthropological theology, theology of the Psalms, modern liturgical canonizations, etc., ${ }^{10}$ and two other researchers are preparing a habilitation.

9 https://www3.unifr.ch/liturgie/fr/recherche/doctorat/th\%C3\%A8ses-termin $\% \mathrm{C}_{3} \%$ Ages. html (22.09.2018).

10 https://www3.unifr.ch/liturgie/fr/recherche/doctorat/th\% $3 \%$ A8ses-en-cours.html (22.09.2018). 
Particularly important are the doctoral programmes in theology of the Conference of the Occidental Swiss Universities, the doctoral interdisciplinary programme "Between Tradition and Innovation" of the Faculty of Theology promoted by "Swissuniversities". In this context, the Institute organizes doctoral study days with a particular interest in the study of liturgical sources in collaboration with the Catholic Institute of Paris and their doctoral study cycle of the Theologicum. The $7^{\text {th }}$ edition of these doctoral study days took place in 2018 , they will be continued in the future. ${ }^{11}$

\subsection{Continuous Learning}

Organization of congresses, colloquia or sessions in liturgy or the liturgy for pastoral work, and participation in training programmes offered by other ecclesiastical bodies (e.g. Liturgisches Institut der deutschsprachigen Schweiz) are another asset of the Institute. ${ }^{12}$

\subsection{Library and documentation}

The Institute is involved in maintaining and extending the liturgical section of the Cantonal and University Library of Fribourg and of the Interfaculty Library of History and Theology of the University (Miséricorde). They have significant library holdings on this field of study in the relevant languages. The Institute is also concerned with keeping an up-to-date record of the publications related to Swiss liturgical history, especially those that discuss the liturgical renewal in modern Switzerland.

\subsection{Main Research projects in theology and history of the liturgy}

In research, the Institute of Liturgical Sciences is one of the assets of the Faculty of Fribourg. Numerous projects ${ }^{13}$ have been carried out over the

\footnotetext{
11 https://www3.unifr.ch/liturgie/fr/recherche/doctorat/journees-doctorales/ (22.09.2018).

12 See point 4, page 9 .

13 The main research areas of the liturgical theology and liturgical history projects are: a) the history of liturgy in the area of today's Switzerland; b) the liturgy at Augustin - in the context of the co-editorship of M. Klöckener for the five-volume Augustinus Lexikon; c) the
} 
past 24 years, led by Prof. Klöckener, ${ }^{14}$ partly in international cooperation. Repeatedly, they were supported by very considerable financial resources from the Swiss National Science Foundation and other research funding agencies (including the "Forschungsfonds" of the University of Fribourg, the "Deutsche Forschungsgemeinschaft").

Twice, the Swiss National Science Foundation promoted the work on the sources edition of Dokumente zur Erneuerung der Liturgie (Documents for the renewal of the liturgy). This project consists of publishing in the German language all the documents of the Apostolic See concerning the liturgy in the four decades after the Constitution Sacrosanctum Concilium (1963-2003). The Second Vatican Council (1962-1965) and the Constitution on the Liturgy (1963) paid particular attention to the worship as the centre of Christian life. According to the decision of the Council, the liturgical reform renewed all the fields of the liturgical life of the Catholic Church in a process of several decades. The reform was oriented to precise theological criteria, was historically grounded, and took into consideration pastoral criteria for the Church in this world.

edition and commentary on medieval liturgical sources - in the context of the source series Spicilegium Friburgense, founded by Anton Hänggi and Gilles Gérard Meersseman in 1957.

14 Martin Klöckener is also an advisor and accompanies different liturgical projects as a member of various Commissions and Associations: Counsellor of the Liturgical Commission of the Swiss Bishops' Conference; Member of the International Commission "Konferenz Liturgie der Kirche im deutschen Sprachgebiet"; President of the Swiss section of the "Arbeitsgemeinschaft Katholischer Liturgikdozentinnen und -dozenten im deutschen Sprachgebiet"; Member of the "Arbeitskreis Liturgik des Kompetenzzentrums Liturgik und Hymnologie" at the University of Bern; Member of the "Kuratorium Liturgisches Institut der deutschsprachigen Schweiz in Freiburg"; Member of the Presidency of the "Verein für die Herausgabe des Katholischen Kirchengesangbuches der Schweiz"; Vice-president of the association "Deutsches Liturgisches Institut e.V.", Trier; Member of the Presidency of the "Abt-Herwegen-Institut Maria Laach e.V."; Member of the scientific council of the review "La Maison-Dieu", Paris; Member of the "Kuratorium Katalogisierung der mittelalterlichen und frühneuzeitlichen Handschriften der Schweiz" of the Swiss Academy of Humanities and Social Sciences; Member of the presidency of the "Rennings-Wagner-Stiftung" Foundation, Trier; Member of the Scientific Council of the "Franz-Stock-Komitee für Deutschland", Arnsberg. 
As part of the first project from 1996-1998, volumes 2 and 3 of the work were edited; ${ }^{15}$ the second project of 2006-2008 prepared the publication of the fourth volume of the Documents according to scientific editorial criteria. ${ }^{16}$ The project was supported for 30 months by the Swiss National Science Foundation.

Another long-term enterprise is the Handbuch der Liturgiewissenschaft "Gottesdienst der Kirche", a handbook of liturgical studies in 12 volumes. Until his death in 2002, the Innsbruck Jesuit Hans Bernhard Meyer bore the main responsibility for the project; the other editors were Hansjörg Auf der Maur, Balthasar Fischer, Angelus A. Häussling OSB and Bruno Kleinheyer. It is now edited by Martin Klöckener and Reinhard Messner (was born 1960) from Innsbruck. ${ }^{17}$ After a long break in 2008, the volume 2.2 was published Theologie des Gottesdienstes ${ }^{18}$ (Theology of worship). From 2007 to 2011, the Swiss National Science Foundation promoted the development of volume 2.1 Theologie und Anthropologie der christlichen Liturgie (Theology and Anthropology of the Christian Liturgy). Since August 2011, with the support of the Swiss National Science Foundation, the research project "Written sources of the liturgy: history, typology, meaning" - "Schriftliche Quellen der Liturgie: Geschichte, Typologie, Bedeutung" (GdK 1.2), has been running again for three years, and the volume 1.2 of the handbook is being prepared. This complex contribution for the Handbuch der Liturgie-

15 See Dokumente zur Erneuerung der Liturgie, Hrsg. H. Rennings, M. Klöckener, Bd. 2, Verlautbarungen des Apostolischen Stuhls, 4.12.1973-3.12.1983, Kevelaer-Fribourg 1997, p. 801; Bd. 3, Verlautbarungen des Apostolischen Stuhls, 4.12.1983-3.12.1993, übersetzen, Hrsg. M. Klöckener with the assistance of Guido Muff, Kevelaer-Freiburg 2001, p. 1114. The first three volumes of the Dokumente zur Erneuerung der Liturgie (covering the period from 1963 to 1993) are currently published by the publisher Butzon \& Bercker, Kevelaer (Germany).

16 Volume 4 Verlautbarungen des Apostolischen Stuhls, 4.12.1993-4.12.2003, Hrsg. M. Klöckener with the assistance of S. Ostermann, A. Zerfass, ca. p. 1700, could not yet be published. It is planned for publication by the end of 2019 .

17 Angelus A. Häussling OSB (1932-2017), of the Abbey of Maria Laach, was also one of the editors of the volume 2.2 .

18 See Theologie des Gottesdienstes. Gottesdienst im Leben der Christen. Christliche und jüdische Liturgie, Hrsg. M. Klöckener, A. Häussling, R. Messner, Regensburg 2008, p. 608 (Handbuch der Liturgiewissenschaft "Gottesdienst der Kirche", 2.2). 
wissenschaft "Gottesdienst der Kirche" prepared by Martin Klöckener, deals with the liturgical sources throughout history and includes the question of scribality and orality in the liturgy, the appearance of the liturgical codex, of its successive development and completion in different types of books, as well as the development of liturgical books printed today. In this context, we take into account the relationship between liturgy and ecclesiology, theological questions of different areas and reciprocal influences between liturgy and culture.

At the same time, volume 1.1 Wissenschaft der Liturgie: Begriff, Geschichte, Konzepte (GdK 1.1) is nearing completion. Martin Klöckener is working on the publication of Volume 1.1 in collaboration with Reinhard Messner (University of Innsbruck), an edition that presents the different denominational profiles of Christian liturgies and focuses on the liturgical sciences as a discipline of Catholic, Protestant, Anglican and Orthodox theology. An international and ecumenical team of theologians from Switzerland, Germany, Austria, France, the United States, Russia and Greece is contributing to this volume.

A significant research project focuses on the Liturgy in North Africa in Late Antiquity, and specifically on Saint Augustine. This field of long-term research results from the co-publication of the Augustinus-Lexikon (5 volumes, Basel 1986) on the part of Martin Klöckener. A series of articles in the Augustinus-Lexikon are the result of this research (see publications on the subject in the bibliography of M. Klöckener ${ }^{19}$ ) which will remain a strong point also in the future. The publication of an anthology on the Eucharistic liturgy by St. Augustine in French is in preparation.

Another remarkable project is involved in the Edition of the primitive Cistercian antiphonary. This research project, based on the palaeographic analysis of the early Cistercian antiphonaries preserved at Tamié (F), Westmalle (B) and La Fille-Dieu (CH), will allow the edition of the chant of the first Cistercian antiphonary. The project will give an account of the chant which was imported from Metz to Cîteaux shortly after 1108 and which was used in all the monasteries of the Order until the beginning of the year 1140. The project, carried out in collaboration with the musicologist

19 See for the complete bibliography: https://admin.unifr.ch/srv-doc-rest/public/documents/451928 (22.09.2018). 
Dr. Alicia Scarcez, represents an important contribution to the knowledge of the oldest version of the Cistercian liturgy. The Swiss National Science Foundation supports this project financially (1.1.2014-31.12.2019).

\section{Scientific conferences and publications. Topics preferred today in the scientific discourse at the Institute for Liturgical Science}

\subsection{Conferences}

In the course of research on the history of liturgy in Switzerland, several international colloquia have been held in recent years, focusing, in particular, on liturgy since the beginning of the twentieth century (the "Liturgical movement") and on its developments since the Second Vatican Council. Most of the results are published in conference proceedings and provide a framework for the further investigation of the recent liturgical history of Switzerland. ${ }^{20}$

\subsection{Selected publications}

Several volumes on subjects of the liturgy today are the fruit of the collaboration with the German Liturgical Institute in Trier at several confe-

20 Should be mentioned: Liturgie in Bewegung. Beiträge zum Kolloquium Gottesdienstliche Erneuerung in den Schweizer Kirchen im 20. Jahrhundert, 1.-3. März 1999 an der Universität Freiburg/Schweiz, Hrsg. B. Bürki, M. Klöckener, Freiburg 2000; Liturgia et Unitas. Liturgiewissenschaftliche und ökumenische Studien zur Eucharistie und zum gottesdienstlichen Leben in der Schweiz, Hrsg. M. Klöckener, A. Join-Lambert, Freiburg 2001; Tagzeitenliturgie. Ökumenische Erfahrungen und Perspektiven, Hrsg. M. Klöckener, B. Bürki, Fribourg 2004; Gottesdienst in Zeitgenossenschaft. Positionsbestimmungen 40 Jahre nach der Liturgiekonstitution des Zweiten Vatikanischen Konzils, Hrsg. M. Klöckener, B. Kranemann, Freiburg 2006; Présence et rôle de la Bible dans la liturgie, sous la rédaction de M. Klöckener, B. Bürki, A. Join-Lambert, Fribourg 2006. The volumes are no longer available from Academic Press Fribourg, but now from "Aschendorffsche Verlagsbuchhandlung" based in Münster (Germany). 
rences (for example, the "Trier Summer Academy"), ${ }^{21}$ about the history of the liturgy, with the Institut Supérieur de Liturgie of the Institut Catholique de Paris ${ }^{22}$ or in collaboration with several German colleagues. ${ }^{23}$

\section{Liturgical sources}

With respect to liturgical sources, two important collections are edited in Fribourg: Spicilegium Friburgense and Spicilegii Friburgensis Subsidia.

The Spicilegium Friburgense collection was founded by the liturgist Anton Hänggi and the church historian Gilles Gérard Meersseman in 1957. It has the status of a Swiss foundation. The objective of the collection is the edition of sources of the Christian life, with a strong emphasis on the Middle Ages. Most editions present liturgical sources. Since its foundation, this collection has seen the birth of almost fifty volumes, many of which have become "classic" editions in the history of the liturgy. ${ }^{24}$ Among the

21 For example, Gottes Volk feiert... Anspruch und Wirklichkeit gegenwärtiger Liturgie, Hrsg. M. Klöckener, E. Nagel, Trier 2002; Liturgie in Wendezeiten. Zwischen konstantinischem Erbe und offener Zukunft, Hrsg. M. Klöckener, A. Urban, Trier 2009.

22 Especially the volume Liturgie, pensée théologique et mentalités religieuses au haut Moyen Âge. Le témoignage des sources liturgiques [Actes de la Journée d'études du 11 mai 2012 organisée par l'Institut d'Études Médiévales et l'Institut Supérieur de Liturgie de l'Institut Catholique de Paris et l'Institut de Sciences Liturgiques de l'Université de Fribourg (Suisse)], éd. H. Bricout, M. Klöckener, Münster 2016 (Liturgiewissenschaftliche Quellen und Forschungen, 106).

23 See for example: Liturgiereformen. Historische Studien zu einem bleibenden Grundzug des christlichen Gottesdienstes. Festschrift Angelus A. Häußling, Hrsg. M. Klöckener, B. Kranemann, Bd. 1, Biblische Modelle und Liturgiereformen von der Frühzeit bis zur Aufklärung; Bd. 2, Liturgiereformen seit der Mitte des 19. Jahrhunderts bis zur Gegenwart, Münster 2002, p. 1224, VII (Liturgiewissenschaftliche Quellen und Forschungen, 88); and recently: Geschichte der Liturgie in den Kirchen des Westens. Rituelle Entwicklungen, theologische Konzepte und kulturelle Kontexte, Bd. 1, Von der Antike bis zur Neuzeit; Bd. 2, Moderne und Gegenwart, Hrsg. J. Bärsch, B. Kranemann in verbindung mit W. Haunerland, M. Klöckener, Münster 2018, p. 604,667 .

24 A. Hänggi, I. Pahl, Prex Eucharistica, Vol. I, Textus e variis liturgiis antiquioribus selecti, 1968 [ $3^{\text {rd }}$ edition, revised by H. Brakmann and A. Gerhards, 1998]; I. Pahl, Coena Domini, Vol. I, 
current projects are several Libri Ordinarii as well as other sources of ecclesial life. The publishing committee is made up of specialists in liturgy, church history and manuscripts.

Both the liturgist Hänggi and the historian Meersseman founded in 1963 the collection Spicilegii Friburgensis Subsidia. From the beginning until today it pursues the following objectives: the publication of research tools in the field of the history of the liturgy; the publication of directories, concordances, catalogues of manuscripts and similar documents. Some of the published works in the series are well-known. ${ }^{25}$ Since 2018, both collections, the Spicilegium Friburgense and the Spicilegii Friburgensis Subsidia, are published by Aschendorff Editions (Münster), where nearly all the volumes of the collections are still available.

The most prestigious German-language international liturgical journal, "Archiv für Liturgiewissenschaft," is edited by Martin Klöckener. Since 1996, he was co-editor and since 2000 chief-editor in the name of the Abt-Herwegen-Institut, Maria Laach.

From its beginning, the "Archiv für Liturgiewissenschaft" (ALw) strove for a broad interdisciplinary integration of the liturgical sciences, which is why the liturgical review "Jahrbuch für Liturgiewissenschaft," the precursor of the "Archiv" and published from 1921 to 1941 by the Abbey of Maria Laach under the care of Odo Casel, particularly has left its mark on the liturgical sciences. Since its inception, the ALw has been committed

Die Abendmahlsliturgie der Reformationskirchen im 16./17. Jahrhundert, 1983, p. 611-XVIII; Vol. II, Die Abendmahlsliturgie der Reformationskirchen vom 18. bis zum frühen 20. Jahrhundert, 2005, p. 780-XX-780; Prex Eucharistica, Vol. III/1, Studia. Pars prima: Ecclesia antiqua et occidentalis, éd. A. Gerhards, H. Brakmann, M. Klöckener, 2005, p. 318-X; J. Deshusses, Le Sacramentaire Grégorien. Ses principales formes d'après les plus anciens manuscrits, Vol. 1: 1971 ( $3^{\text {rd }}$ edition 1992); Vol. 2: 1979 (2 $2^{\text {nd }}$ edition 1988); Vol. 3: 1982 (2 $2^{\text {nd }}$ edition 1992).

25 K. Gamber, Codices liturgici latini antiquiores. Reliquiae liturgiae africanae. Libri liturgici celtici, gallicani, mozarabici, campani, beneventani et ambrosiani. Sacramentaria, Capitularia, Lectionaria, Antiphonaria, Missalia, Collectaria, Pontificalia, Ritualia, Vol. 1-2, 2 éd., 1968, p. 652, and a Supplementum, 1988, p. 234; J. Deshusses and B. Darragon, Concordances et tableaux pour l'étude des grands Sacramentaires, 6 vols., 1982-1983; Iter Helveticum, 5 vols., 1976-1990; A. Scarcez, Liturgie et musique à l'Abbaye cistercienne Notre-Dame de la Fille-Dieu (Romont). Histoire et catalogue des sources de sept siècles de vie chorale, 2015, p. 240. 
to respecting the tradition of Western churches, yet its fair value can only be appreciated in ecumenical terms.

The members of the editorial board are currently Martin Klöckener, Benedikt Kranemann (University of Erfurt), Cyprian Krause OSB (Maria Laach/Rome) and Alexander Zerfass (University of Salzburg). About 25 permanent collaborators from several countries are involved, and between 500 and 600 pages of specialized contributions and literature reports are produced per year. The editorial office is located at Maria Laach's German Abbey which supports the company financially.

The ALw publishes research tools in the form of texts, press articles, reviews and bibliographies. All these tools, as well as literary opinions, are exploited, year after year, in the form of complex indexes of people and subjects.

Literary reviews report on all types of specialized publications: monographs, collections, major periodicals, non-independent literature, and others. With regard to the literature of other theological or non-theological disciplines, what is relevant for the research of the liturgical sciences is taken as a criterion.

\section{Conclusion}

There have been a number of crucial events in the life of the Church in the $20^{\text {th }}$ century, such as the Liturgical movement, the theological and ecclesiological renewal, the Second Vatican Council, and the restless studies in the history and structures of the liturgy. These events have posed higher challenges and requirements on the field of Theology and more specifically on the field of liturgical research. The chair and, later on, Institute of Liturgical Sciences in the Faculty of Theology in Fribourg University have acted in response to these ever-increasing standards in a pragmatic way. Its commitment and pioneering spirit are evident in the fact that the chair of Liturgical Studies has been endowed twice in 1900 and once more in 1956. I personally consider that through their tireless effort over the past decades, the Institute of Liturgical Sciences and the University of Fribourg Faculty of Theology have led the way for the other researchers and institutes in the field to follow.

The responsible vision of the Fribourg Faculty of Theology in its contribution to liturgical science is perfectly expressed by the main actors 
themselves. In the preface of a book dedicated to the history and activity of the Institute, the professors of this chair wrote:

\begin{abstract}
The number of initiatives and impulses for theology, and especially for liturgical science that arose in Fribourg on the frontier of French and German languages and cultures, over the last five decades, is striking. The thematic amplitude and seriousness related to this discipline are no less so. Although the professors and scientific collaborators have organized their work in different ways and focused on changing priorities, continuity in basic options is obvious. In day-to-day operations, it cannot be guessed at first glance. It is important to remember that university activity is not simply a matter for initiates, but that it has a clear influence on the Church and on society. In liturgical science it has also, in Fribourg more than in many other academic places, gained from the benefits of a stimulating ecumenical cooperation, while enriching it in return..$^{26}$
\end{abstract}

\title{
Streszczenie
}

\section{Źródta liturgii i teologia liturgiczna w Instytucie Nauk Liturgicznych we Fryburgu}

Wydział Teologiczny Uniwersytetu we Fryburgu wytyczył nowy kierunek w międzynarodowym środowisku, tworząc katedrę nauk liturgicznych w latach 1900 i 1910 . Jej szefem był prof. Max von Sachsen, szczególnie wyczulony na liturgię Kościołów wschodnich. Nowa stała katedra nauk liturgicznych została ustanowiona w 1956 roku, przed soborem watykańskim II. Władze Wydziału Teologicznego nadały jej formę instytutu w 1999 roku. Dwujęzyczny charakter uniwersytetu (niemiecko-francuski) oferuje możliwości spotkań i wymiany różnych poglądów, tradycji teologicznych, form życia, mentalności i kultur na polu liturgii. Doceniając źródła liturgiczne, Wydział Teologiczny publikuje dwie ważne serie pod patronatem Instytutu: Spicilegium Friburgense i Spicilegii Friburgensis Subsidia. Od 1996 roku najbardziej prestiżowy niemieckojęzyczny, międzynarodowy periodyk liturgiczny "Archiv für Liturgiewissenschaft" był redagowany przez prof. Martina Klöckenera, powołanego na szefa tej katedry w 1994 roku.

26 M. Klöckener, B. Bürki, Préface des éditeurs, in: Der Zeit voraus - Devancer son époque, p. 15. 